\title{
PEMBUATAN BAHAN ACUAN BAKU UNTUK ANALISIS CONTO MANGAN
}

\section{THE ESTABLISHMENT OF ANALYSIS STANDARD REFERENCE MATERIAL FOR MANGANESE SAMPLE}

\author{
Nining Widaningsih dan Herry Rodiana Eddy \\ Pusat Sumber Daya Mineral, Batubara dan Panas Bumi \\ nwidaningsih@yahoo.com
}

\begin{abstract}
ABSTRAK
Pembuatan bahan acuan baku untuk analisis conto mangan dilakukan guna mencari alternatif lain dari penggunaan Certified Reference Material produksi lembaga asing yang harganya relatif mahal serta jumlahnya yang terbatas. Conto mangan yang digunakan untuk bahan acuan baku diperoleh dari wilayah konsesi PT Arumbai Mangabekti, di Desa Satar Punda, Kecamatan Lamba Leda, Kabupaten Manggarai Timur, Provinsi Nusa Tenggara Timur dan di Desa Pace, Kecamatan Silo, Kabupaten Jember, Provinsi Jawa Timur. Berdasarkan International Manganese Institute, conto mangan yang memiliki kandungan $\mathrm{Mn}$ total berkisar antara $35 \%$ s.d. $48 \%$ dikategorikan sedang, dan yang lebih besar dari $50 \%$, tinggi. Kegiatan pemercontoan di Kabupaten Manggarai Timur dengan kode conto BWN, SATARNANI dan STN-2, sedangkan di Kabupaten Jember dengan kode conto SDG-1. Preparasi conto mangan dilakukan di Laboratorium Pusat Sumber Daya Mineral, Batubara dan Panas Bumi, untuk mendapatkan conto yang homogen dengan ukuran 150 mesh. Analisis kimia dilakukan untuk menentukan major dan minor elements yang terkandung di dalam conto mangan. Data hasil analisis kimia yang dilakukan di delapan laboratorium termasuk Laboratorium Pusat Sumber Daya Mineral, Batubara dan Panas Bumi, kemudian dilakukan pengolahan data dengan beberapa metoda statistik. Hasil pengolahan data menunjukkan bahwa ke empat conto tersebut memenuhi kriteria kandungan Mn total kadar sedang dan tinggi. Conto bahan acuan baku dengan kriteria kandungan Mn total kadar sedang terdapat pada kode conto BWN (Mn total 35,01\%), kode conto SATARNANI (Mn total $44,24 \%$ ) dan SDG-1 (Mn total 48,90\%), sedangkan kandungan Mn total kadar tinggi terdapat pada kode conto STN-2 (Mn total 55,85\%).
\end{abstract}

Kata kunci: bahan acuan baku, mangan, analisis laboratorium, Desa Satar Punda, Desa Pace

\section{ABSTRACT}

Standard reference material for manganese is established to provide an alternative to the use of Certified Reference Material/CRM from foreign institutions that are relatively more expensive and limited. The manganese sample used for reference material was obtained from the concession area of PT Arumbai Mangabekti, in Satar Punda Village, Lamba Leda District, East Manggarai Regency, East Nusa Tenggara Province and in Pace Village, Silo District, Jember Regency, East Java Province. Base on classifies manganese International Manganese Institute, the manganese sample was the one which has a total Mn content of about 35\% - 48\% (moderate), and > 50\% (high). Sampling activiti in East Manggarai District was coded with BWN, SATARNANI and STN-2, while sampling activitiy in Jember District was coded with SDG-1. The manganese sample preparation was done in the laboratory of the Center for Mineral, Coal and Geothermal Resources to obtain a homogenous sample of 150 mesh. Chemical analysis was performed to determine the major and minor elements contained in the manganese sample. After obtaining the data of chemical analysis conducted in 8 laboratories included laboratory of Center for Mineral, Coal and Geothermal Resources then data processing was performed with several statistical method. The results of data 
processing showed that the four in-house standard samples meet the criteria of medium and high total Mn content. Standard contents with the criteria of medium total Mn content was found in the BWN (total Mn of 35.01\%), SATARNANI (total Mn of 44.24\%) and SDG-1 (total Mn of 48.90\%), whereas the high total Mn content was found in the STN-2 (total Mn of $55.85 \%)$.

Keywords: standard reference material, manganese, laboratory analysis, Satar Punda Village, Pace Village.

\section{PENDAHULUAN}

Bahan acuan baku (standard reference material) berfungsi sebagai pengendali jaminan mutu hasil analisis kimia bisa didapatkan dari lembaga tertentu, misalnya NIST dari Amerika yang disebut Certified Reference Material (CRM). Bahan acuan tersebut memiliki peran penting di dalam proses analisis kimia karena fungsinya sebagai acuan untuk menentukan konsentrasi analit yang tidak diketahui atau untuk kalibrasi peralatan ukur kimia. Dengan bahan acuan baku tersebut diharapkan hasil analisis kimia menjadi lebih akurat atau mendekati nilai sebenarnya (true value). Penentuan keakuratan suatu proses analisis kimia memerlukan proses kalibrasi alat dengan bahan acuan yang telah diketahui konsentrasinya. CRM tersebut dilengkapi dengan sertifikat yang berisi informasi tentang nama bahan dan konsentrasi kimia penyusun bahan acuan. Oleh karena harganya sangat mahal dan ketersediaannya terbatas maka alternatif lain dengan membuat sendiri.

Bahan acuan baku tersebut dapat digunakan dalam analisis kimia, apabila memenuhi beberapa persyaratan, diantaranya stabil dalam periode waktu penggunaannya, homogen pada kuantitas conto yang ditimbang untuk analisis, memiliki matriks yang mirip dengan matriks conto-conto yang dianalisis secara rutin, berkadar analit yang mendekati kadar conto yang dianalisis dan tersedia dalam kuantitas yang mencukupi.

Conto yang secara rutin dianalisis yaitu mangan, yang dikenal dari ciri-ciri fisiknya, yaitu warna cenderung kehitaman, dan berat jenis tinggi. Analisis mangan di laboratorium meliputi penentuan major elements dan minor elements. Dalam pelaksanaannya analisis kimia tersebut juga membutuhkan bahan acuan baku yang telah diketahui konsentrasi major elements dan minor elements-nya.

Tujuan pembuatan bahan acuan baku untuk analisis conto mangan yaitu mendapatkan conto standar mangan yang selalu siap digunakan untuk kegiatan analisis sehingga diperoleh hasil analisis yang terjamin/terkendali mutunya dan lebih ekonomis. Bahan acuan baku tersebut diharapkan dapat menggantikan bahan acuan baku produk luar negeri.

\section{METODOLOGI}

Tahapan pembuatan bahan acuan baku meliputi studi literatur, pemercontoan mangan, menganalisis conto, dan mengolah data baik di laboratorium internal maupun eksternal. Analisis eksternal dilakukan di tujuh laboratorium dan analisis internal di Laboratorium Pusat Sumber Daya Mineral, Batubara dan Panas Bumi. Pengolahan data hasil analisis tersebut menggunakan metode statistik seperti; uji Histogram, uji Dixon dan uji Z-Score (Anonim, 2004; Kartika, 2006; Elishian, 2014).

\section{Permercontoan Mangan}

Kegiatan pemercontoan mangan di lapangan dapat dibagi menjadi beberapa tahapan yaitu:

\section{Pengambilan Conto}

Pengambilan conto mangan dilakukan di dua daerah yaitu di Kabupaten Manggarai Timur dan Kabupaten Jember. 
Di Kabupaten Manggarai Timur, pengambilan conto mangan di Wilayah IUP PT Arumbai Mangabekti, Desa Satar Punda, Kecamatan Lamba Leda, diambil sebanyak tiga conto dengan cara grab sampling sejumlah kurang lebih $40 \mathrm{~kg}$ sampai dengan $60 \mathrm{~kg}$ (Davis, and Hartati, 1991). Endapan mangan mengelompok menempati rongga dalam zona batugamping yang massif, pada Formasi
Kiro (Sukmana, 2006). Satu conto berkadar Mn tinggi diambil dari stock pile, diberi kode conto STN-2, sedangkan dua conto lainnya diperkirakan berkadar $\mathrm{Mn}$ sedang yang diambil pada titik koordinat $120^{\circ} 30^{\prime} 37,3^{\prime \prime}$ BT - 8¹7'55,2''LS dan pada titik koordinat $120^{\circ} 30^{\prime} 43,9^{\prime \prime} B T$ $8^{\circ} 17^{\prime} 06,0^{\prime \prime}$ LS dengan kode conto BWN dan SATARNANI (Gambar 1 dan Gambar 2).

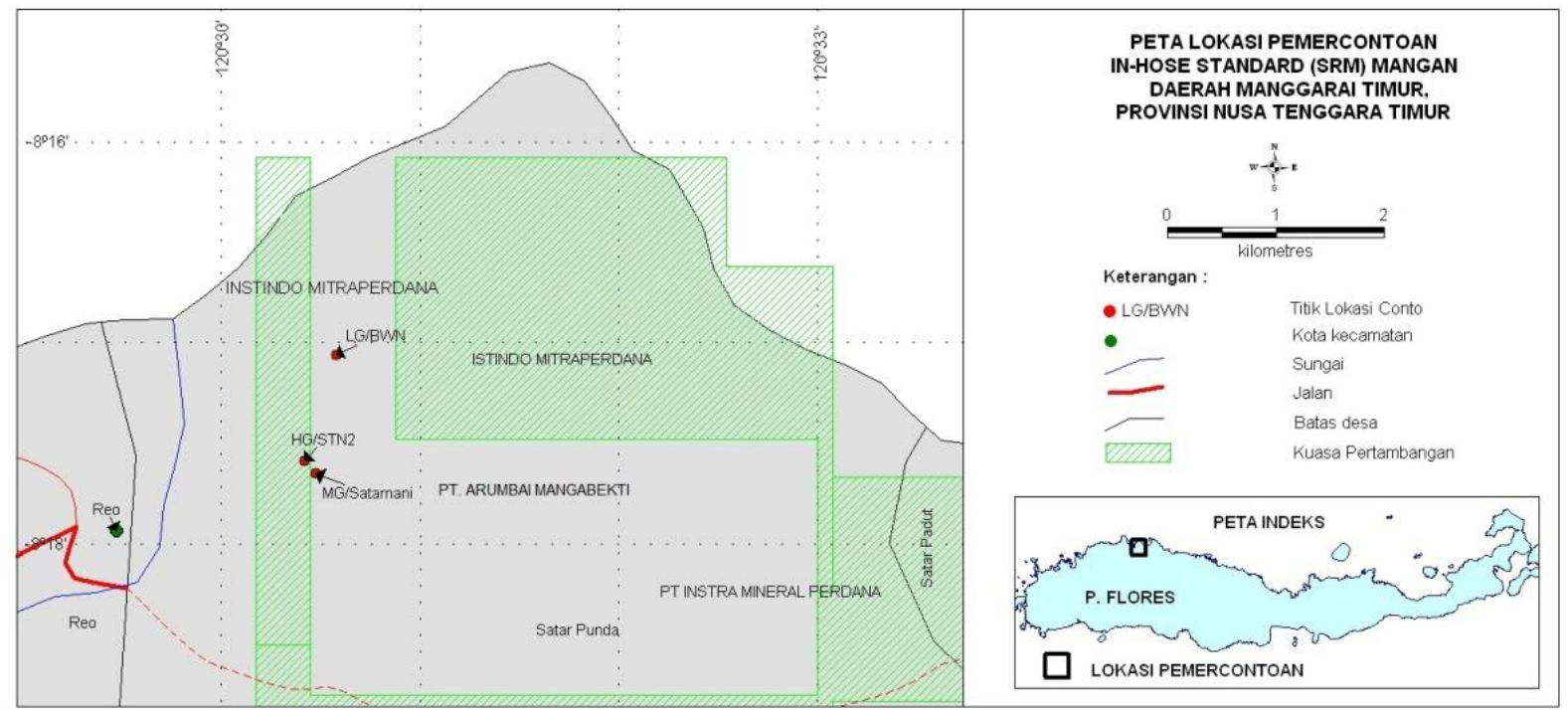

Gambar 1. Peta Lokasi Pengambilan Conto di Wilayah IUP PT Arumbai Mangabekti, Desa Satar Punda, Kecamatan Lamba Leda

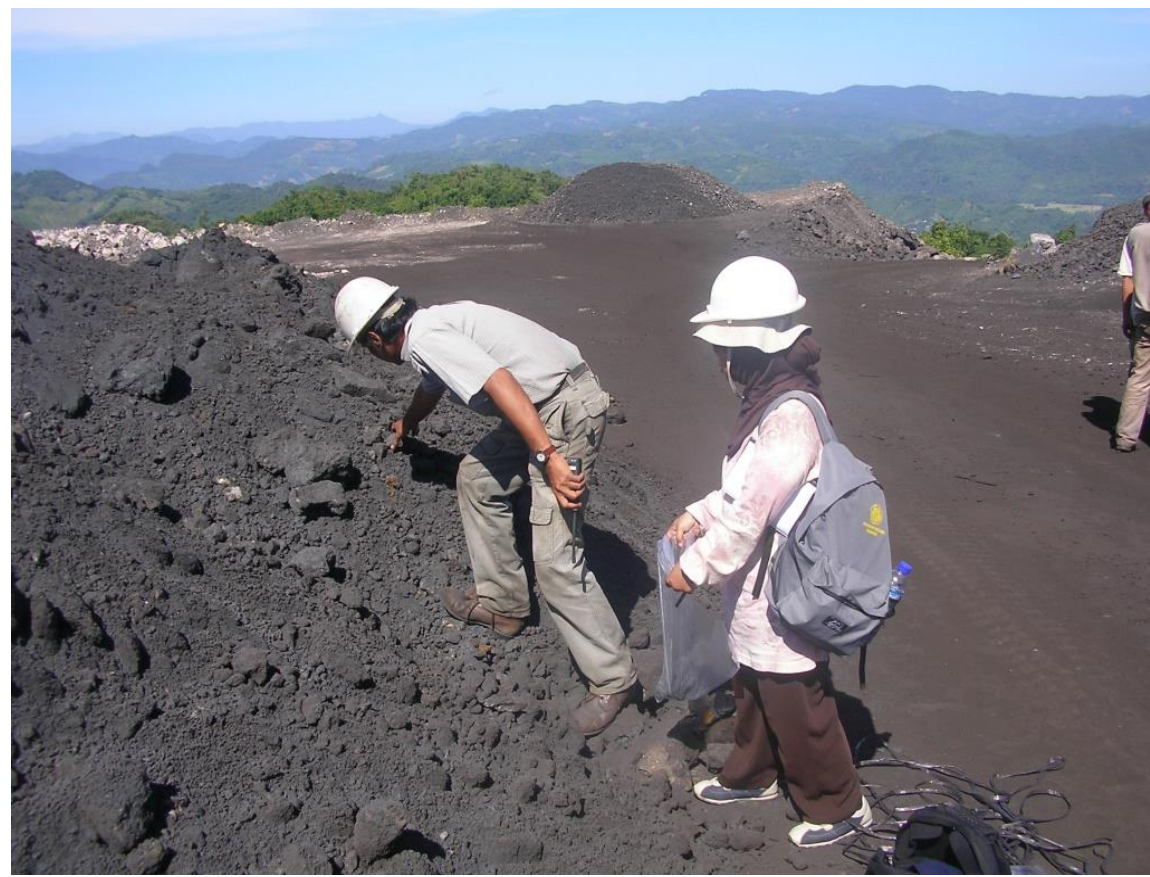

Gambar 2. Pengambilan conto mangan berkadar Mn tinggi, lokasi di stock pile PT Arumbai Mangabekti 
Di Kabupaten Jember, Provinsi Jawa Timur, pengambilan conto mangan di Desa Pace, Kecamatan Silo, yang berkadar $\mathrm{Mn}$ tinggi dengan cara grab sampling sejumlah $50 \mathrm{~kg}$ pada titik koordinat $113^{\circ} 51^{\prime} 29,4$ " BT -8 $8^{\circ} 17^{\prime} 29,5^{\prime \prime}$ LS dengan kode conto CMP-1 dan satu conto lagi yang berkadar Mn sedang yang diambil di Desa Grendeng, Kecamatan Puger pada titik koordinat $113^{\circ} 28^{\prime} 41,3^{\prime \prime}$ BT -8 $8^{\circ} 28^{\prime} 41,3^{\prime \prime}$ LS dengan kode conto SDG-1. (Gambar 3 dan Gambar 4). Mangan terdapat berupa lensa-lensa pada kontak antara batugamping dengan tuf (Anonim, 2016).
Kedua conto tersebut (CMP-1, dan SDG1) dihancurkan, dikeringkan, dan diquartering sampai diperoleh berat lebih kurang $40 \mathrm{~kg}$, kemudian dimasukkan ke dalam karung plastik yang telah diberi label (nomor conto, kode conto dan kode lokasi).

Hasil pengambilan conto dari Kabupaten Manggarai Timur dan Kabupaten Jember selanjutnya dikemas dan dikirim ke Laboratorium Pusat Sumber Daya Mineral, Batubara dan Panas Bumi, Jalan Soekarno Hatta Nomor 444 Bandung.

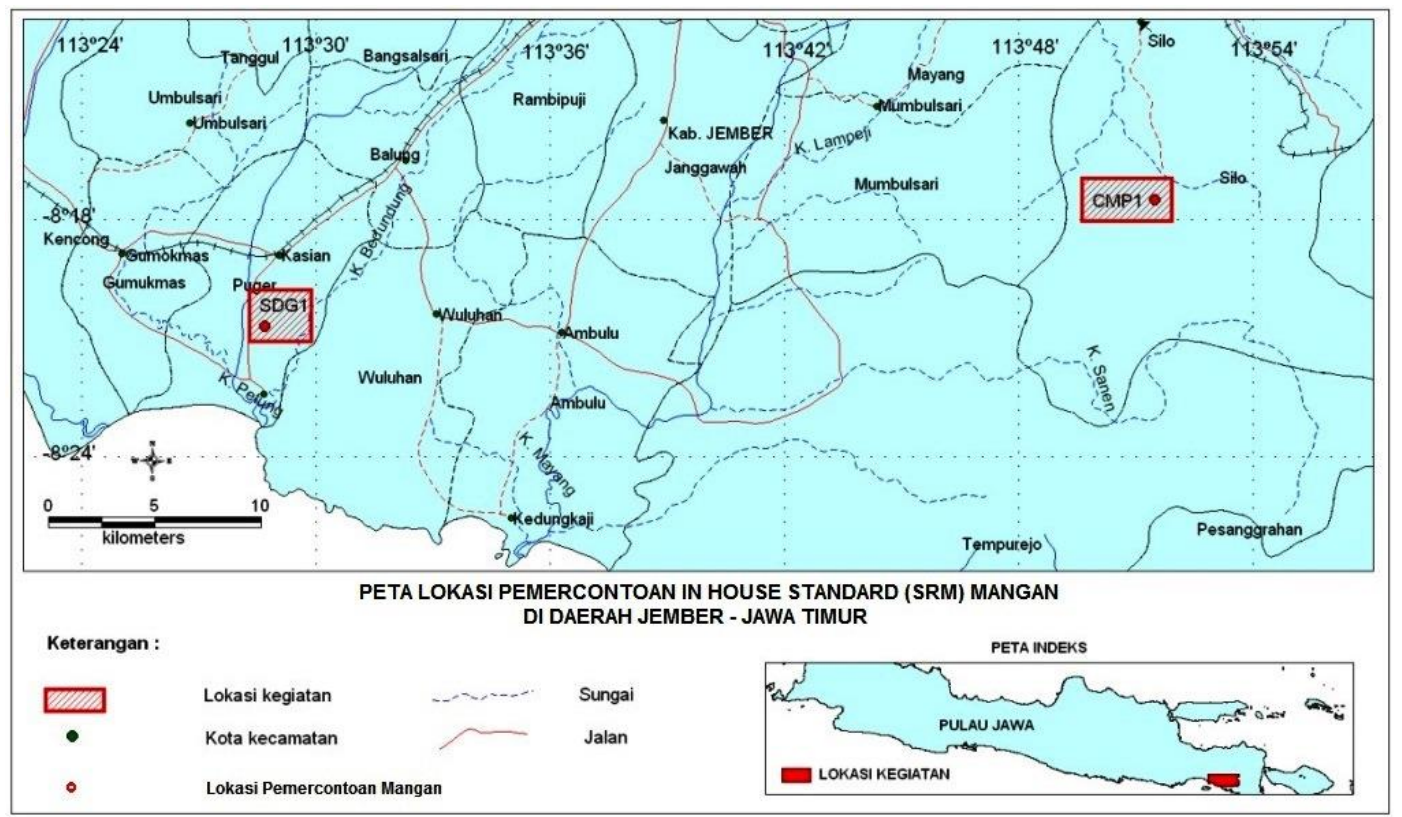

Gambar 3. Peta lokasi pengambilan conto di Kabupaten Jember, Provinsi Jawa Timur

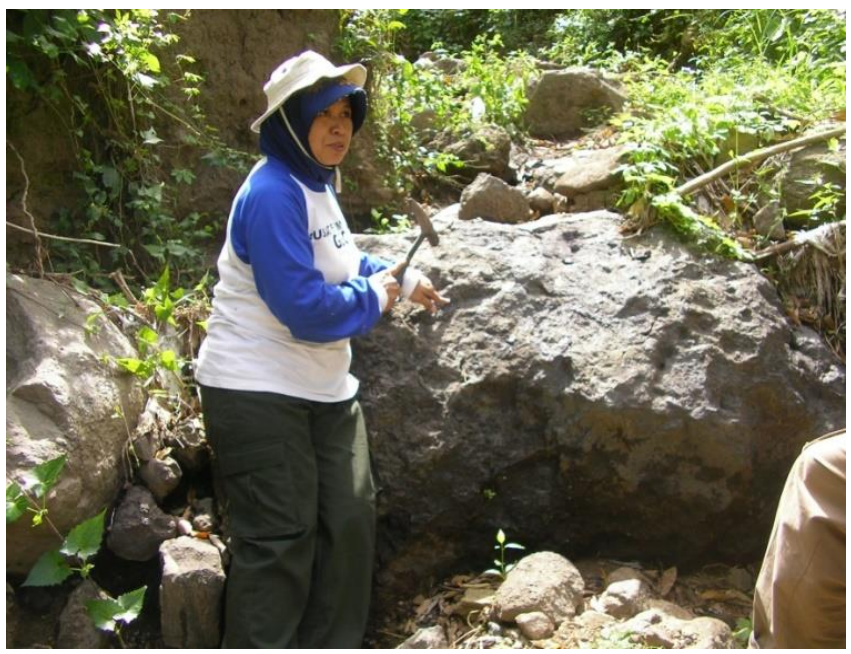

Gambar 4. Keterdapatan bijih mangan sebagai boulder di Desa Pace, Kecamatan Silo, Kabupaten Jember, Provinsi Jawa Timur 


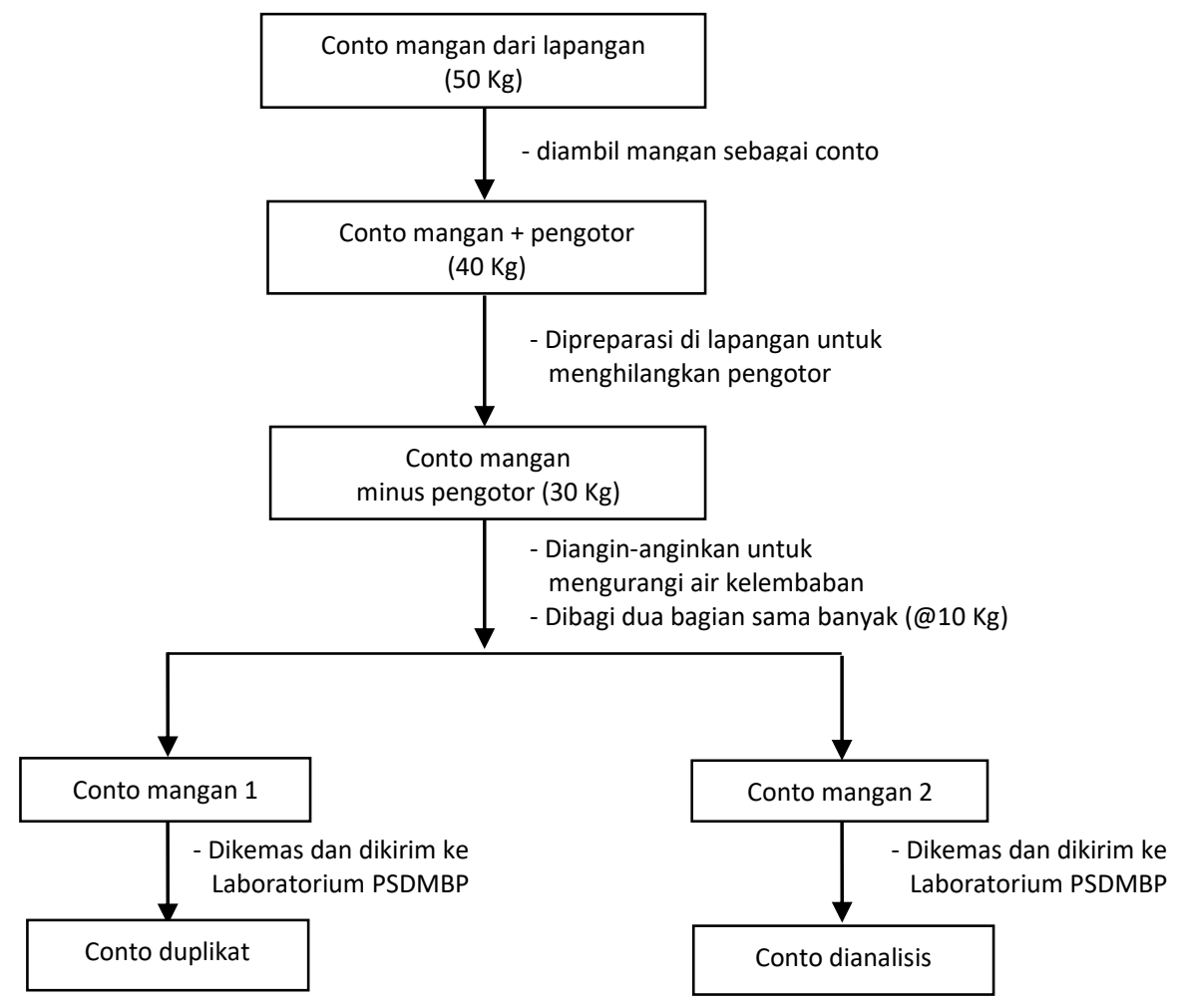

Gambar 5. Bagan alir pengambilan conto mangan dan penanganannya di lapangan

Metoda pengambilan conto di lapangan dilakukan secara acak dengan metoda grab sampling untuk pengambilan conto dari stock pile dan metoda channel sampling untuk pengambilan conto di daerah mineralisasi, sebanyak lebih kurang $40 \mathrm{~kg}$ sampai dengan $60 \mathrm{~kg}$, kemudian dimasukkan dan diikat dalam karung plastik (Gambar 6).

\section{Metoda Preparasi Conto di Laboratorium}

Preparasi conto di laboratorium dengan cara menghaluskan, menjadikan conto homogen dan membagi conto sampai diperoleh sejumlah conto yang diinginkan (Gambar 6, Gambar 7, Gambar 8 dan Gambar 9).

Conto yang sudah homogen dibagi dengan cara coning and quartering menjadi dua bagian yang sama, menyimpan satu bagian $(10 \mathrm{~kg})$ sebagai duplikat conto halus (150 mesh), kemudian disimpan di tempat kedap udara, dan yang satu bagian lagi $(10 \mathrm{~kg})$ dibagi dengan jumlah yang sama (100 gram) menggunakan rotary devider. (Gambar 10 dan Gambar 11) Setelah itu conto dimasukkan ke dalam botol conto (ukuran $150 \mathrm{ml}$ ), selanjutnya mengirimkan minimal delapan botol conto ke Laboratorium Pusat Sumber Daya Mineral, Batubara dan Panas Bumi serta ke masing-masing laboratorium terakreditasi Komite Akreditasi Nasional di luar untuk uji banding atau uji profisiensi (Dubai Accreditation Center, 2008).

Secara garis besar langkah preparasi conto di laboratorium dapat dilihat pada bagan alir Gambar 12. 


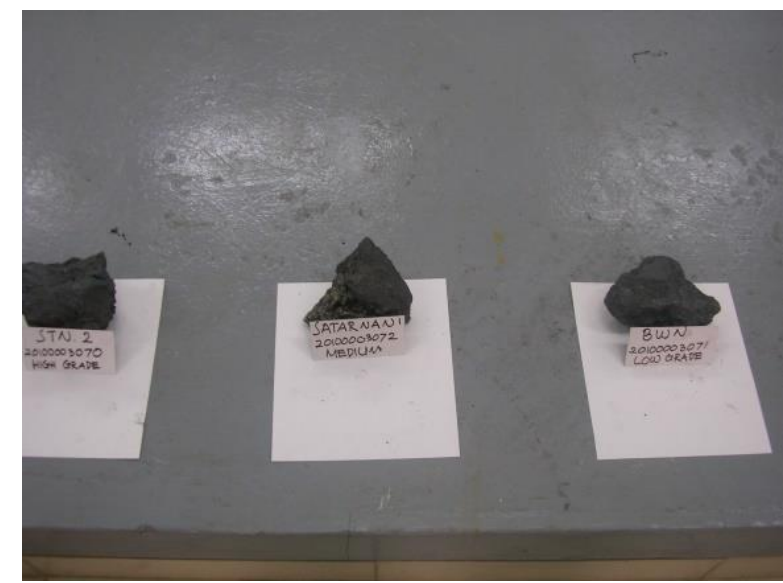

Gambar 6. Conto mangan dari lapangan

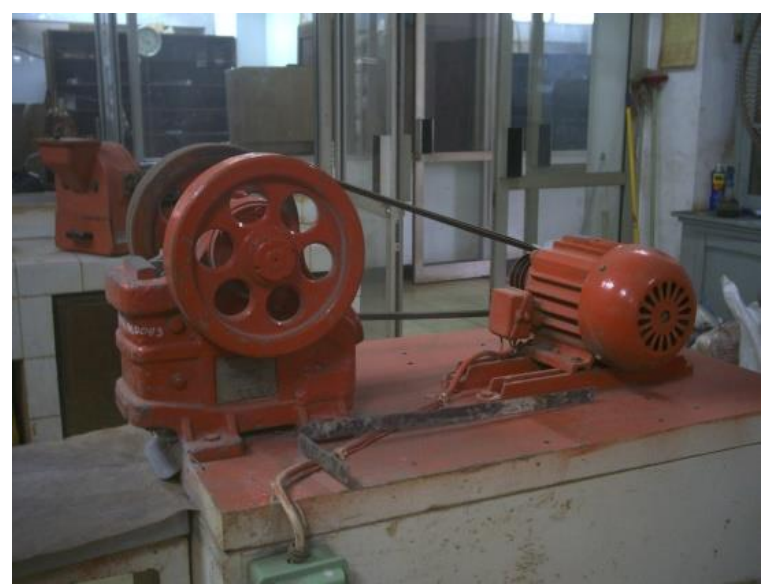

Gambar 8. Alat Gerus Jaw Crusher

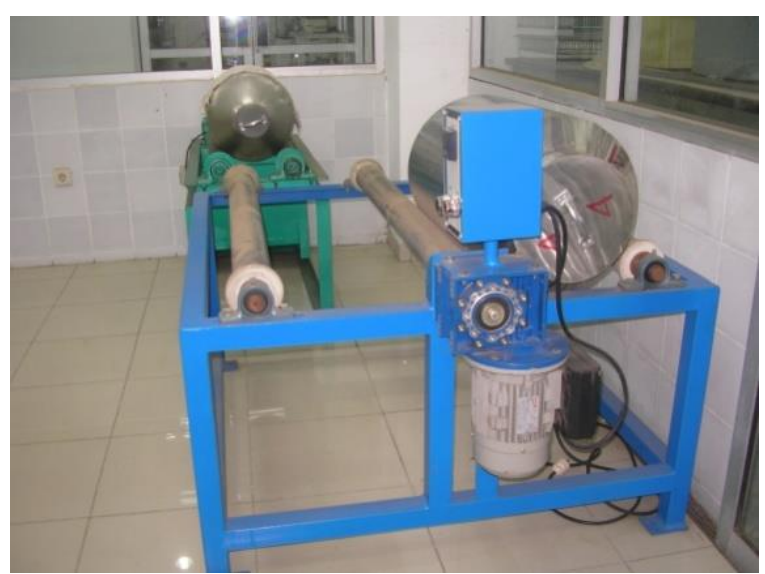

Gambar 10. Blending Machine untuk menghomogenkan conto

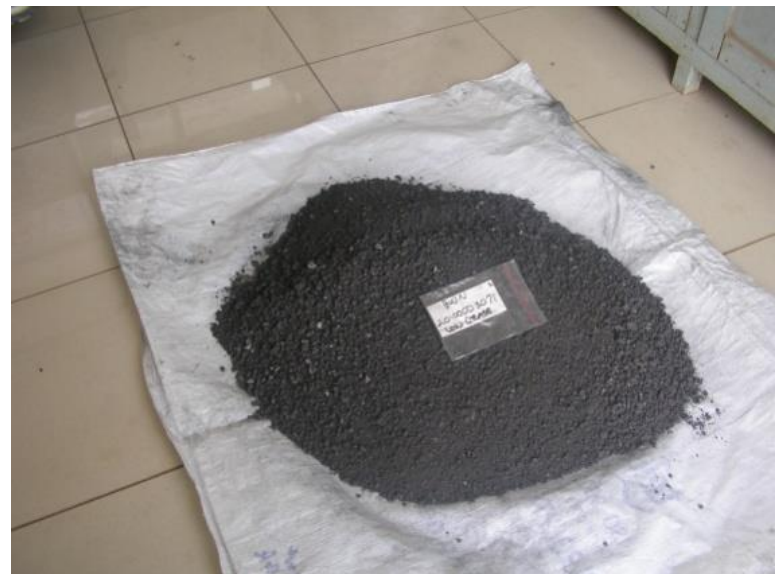

Gambar 7. Conto mangan kasar setelah digerus

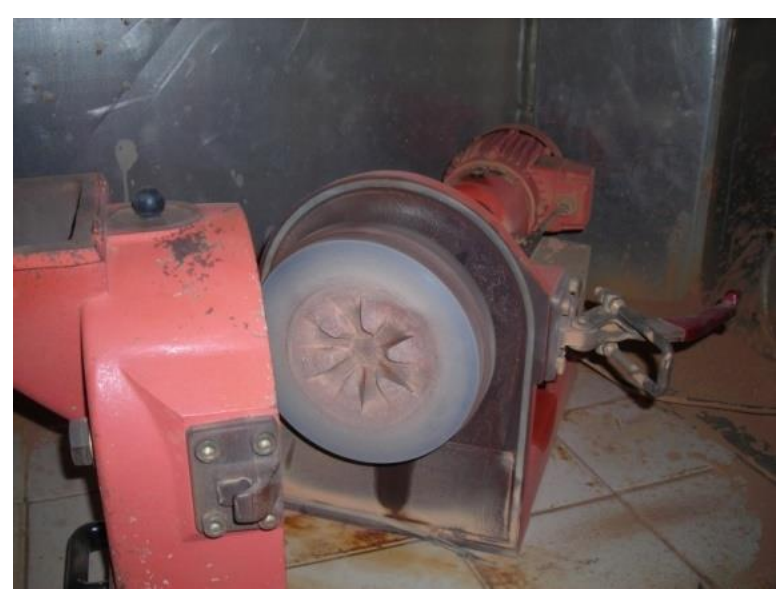

Gambar 9. Alat Gerus Pulveryzeer

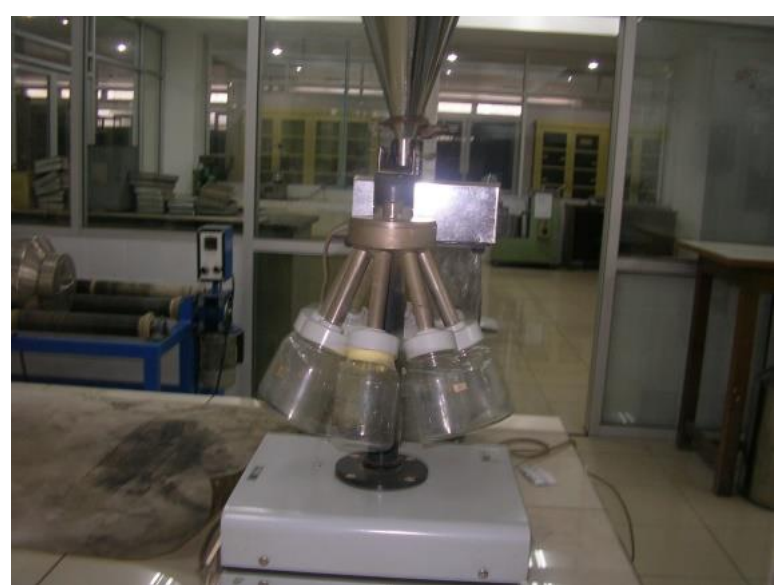

Gambar 11. Rotary Devider 


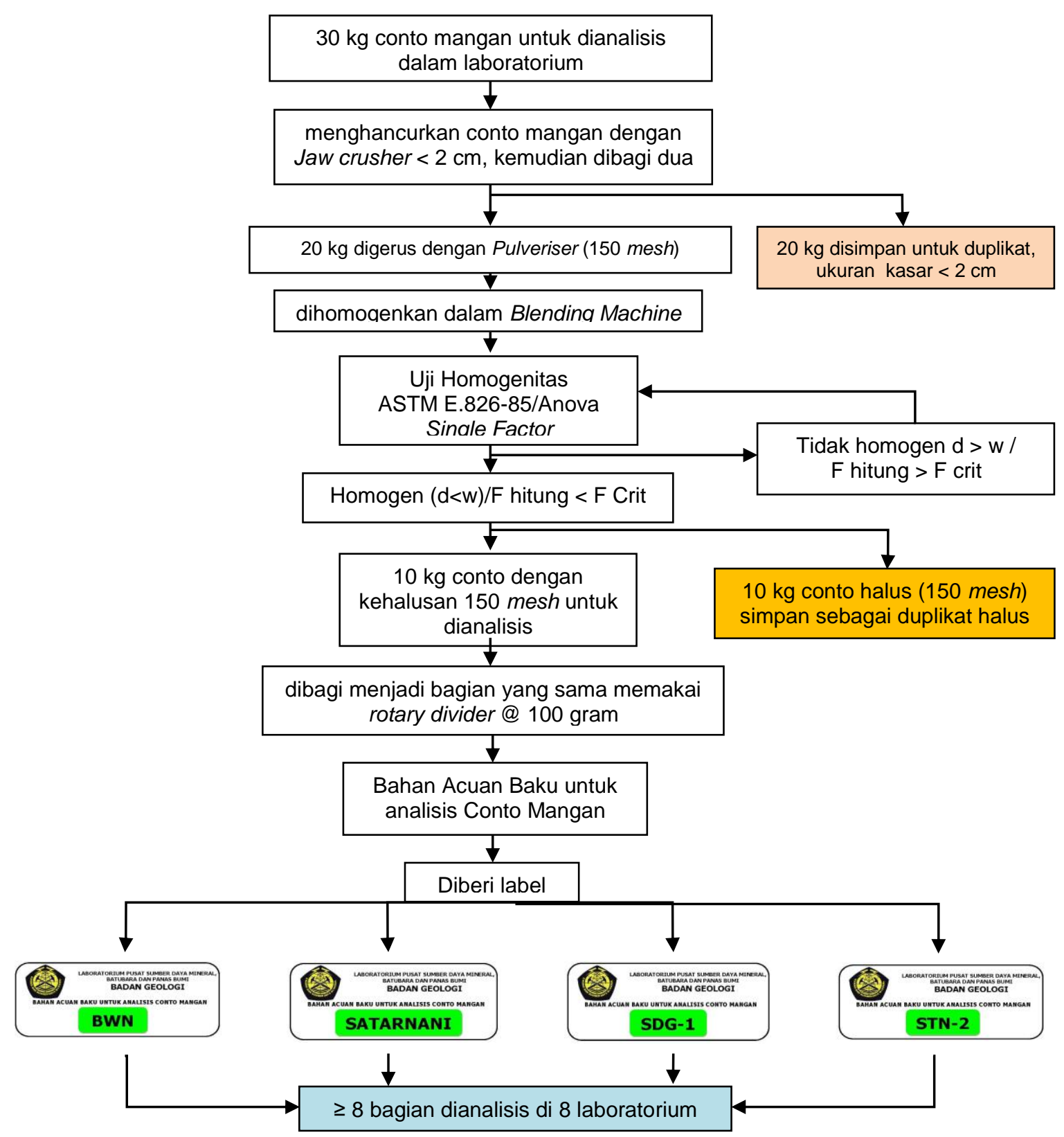

Gambar 12. Bagan Alir Preparasi Conto Mangan di Laboratorium

\section{Metoda Analisis Conto Mangan}

Analisis conto mangan meliputi metoda basah atau konvensional (Gambar 13), Spectrophotometer (Gambar 14), Atomic Absorption Spectrophotometer/AAS (Gambar 15), X-Ray Fluorosence/X-RF (Gambar 16) dengan parameter major dan minor elements $\left(\mathrm{SiO}_{2}, \mathrm{Al}_{2} \mathrm{O}_{3}, \mathrm{Fe}_{2} \mathrm{O}_{3}, \mathrm{MnO}_{2}\right.$, $\mathrm{Mn}$ total, $\mathrm{MnO}, \mathrm{P}_{2} \mathrm{O}_{5}, \mathrm{~S}$ total, $\mathrm{H}_{2} \mathrm{O}$, dan $\mathrm{HD}$ ), dapat juga analisis dilakukan hanya terhadap parameter yang dominan atau mayor, analisis ini disebut analisis partial, analisis mineral dilakukan dengan metoda $X$-Ray Diffraction/X-RD (Gambar 17).

Analisis mangan di Laboratorium Pusat Sumber Daya Mineral, Batubara dan Panas Bumi terdiri dari 10 parameter yaitu $\mathrm{SiO}_{2}, \mathrm{Al}_{2} \mathrm{O}_{3}, \mathrm{Fe}_{2} \mathrm{O}_{3}, \mathrm{MnO}_{2}, \mathrm{Mn}$ total, $\mathrm{MnO}$, $\mathrm{P}_{2} \mathrm{O}_{5}$, S total, $\mathrm{H}_{2} \mathrm{O}$, dan $\mathrm{HD}$ (Leonard Shapiro, 1978), seperti terlihat Tabel 1. 
Tabel 1. Metoda Analisis Kimia Conto Mangan

\begin{tabular}{cll}
\hline No. & Parameter & Metoda yang digunakan \\
\hline 1 & $\mathrm{SiO}_{2}$ & Gravimetri \\
\hline 2 & $\mathrm{Al}_{2} \mathrm{O}_{3}$ & $A A S / X-R F$ \\
\hline 3 & $\mathrm{Fe}_{2} \mathrm{O}_{3}$ & $A A S / X-R F$ \\
\hline 4 & $\mathrm{MnO}$ & Perhitungan \\
\hline 5 & $\mathrm{MnO}_{2}$ & Permanganometri \\
\hline 6 & $\mathrm{Mn}$ total & Permanganometri \\
\hline 7 & $\mathrm{P}_{2} \mathrm{O}_{5}$ & Spectrophotometri \\
\hline 8 & $\mathrm{~S}$ total & Gravimetri \\
\hline 9 & $\mathrm{H}_{2} \mathrm{O}$ & Gravimetri \\
\hline 10 & $\mathrm{HD} / \mathrm{LO}$ & Gravimetri \\
\hline 11 & Mineral & $X-R D$ \\
\hline
\end{tabular}

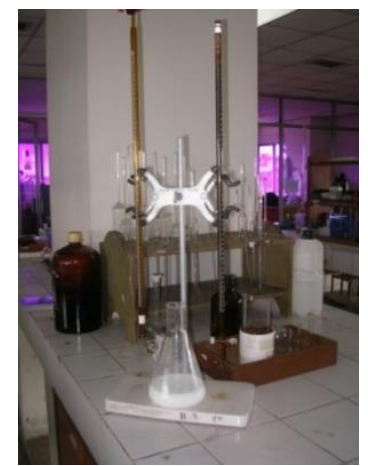

Gambar 13. Peralatan titrasi metoda basah (konvensional)

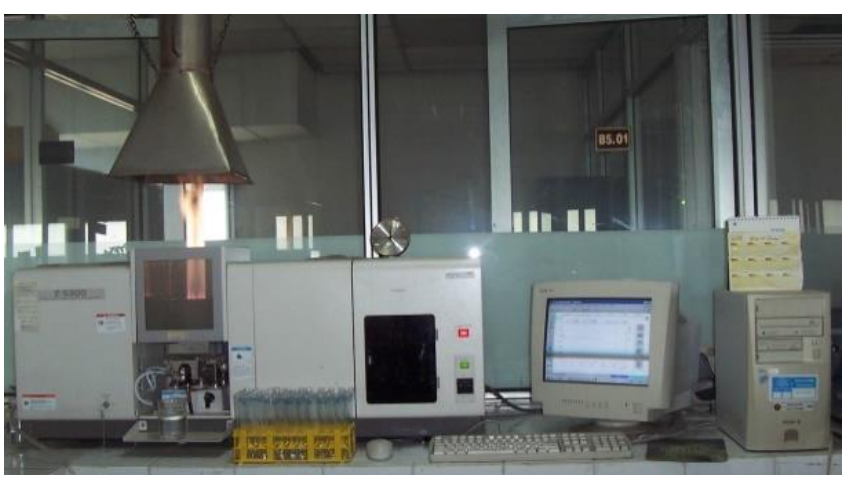

Gambar 15. AAS Hitachi Zeeman

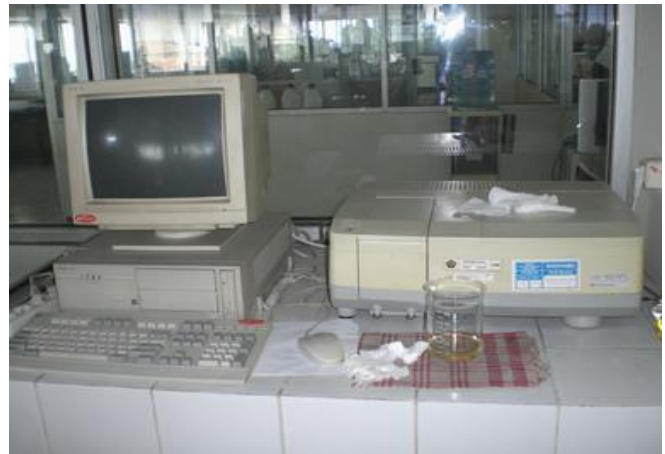

Gambar 14. Spectrophotometer UVIVIS

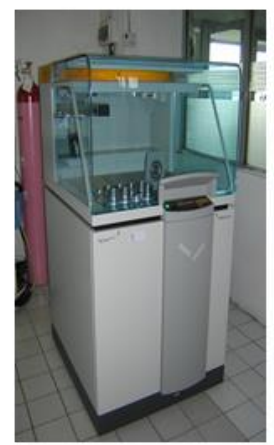

Gambar 16. X-Ray Fluorosence $(X-R F)$

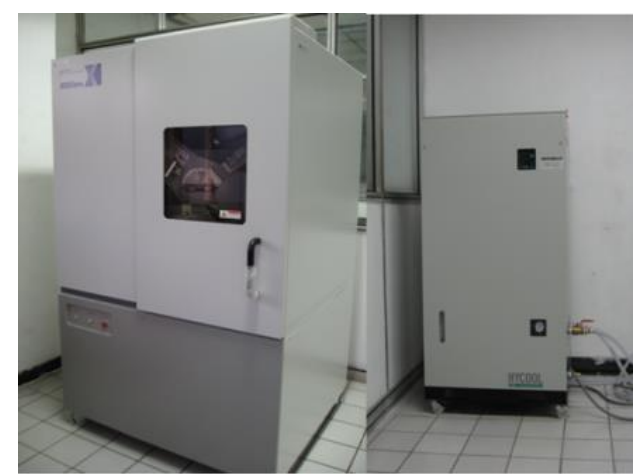

Gambar 17. X-Ray Diffraction $(X-R D)$ 


\section{Hasil Pelabelan}

Daftar label pembuatan bahan acuan baku conto mangan dengan kode conto
SATARNANI, BWN, STN-2, dan SDG-1, seperti terlihat pada Tabel 2 berikut ini.

Tabel 2. Daftar Label Pembuatan Bahan Acuan Baku Conto Mangan No. Kode conto dari lapangan Label bahan acuan baku

1 SATARNANI

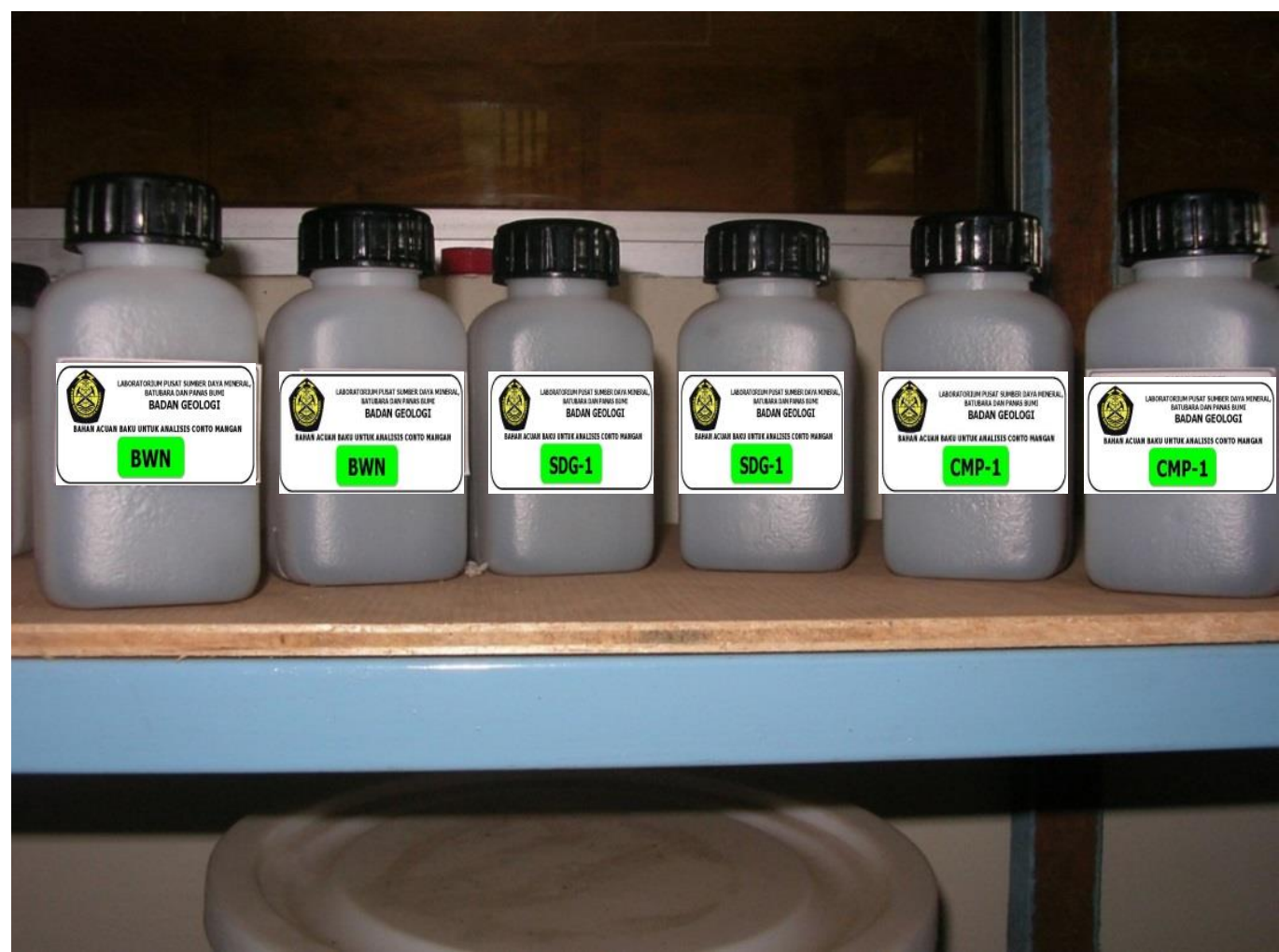

Gambar 18. Bahan acuan baku conto mangan dalam kemasan botol 100 gram 


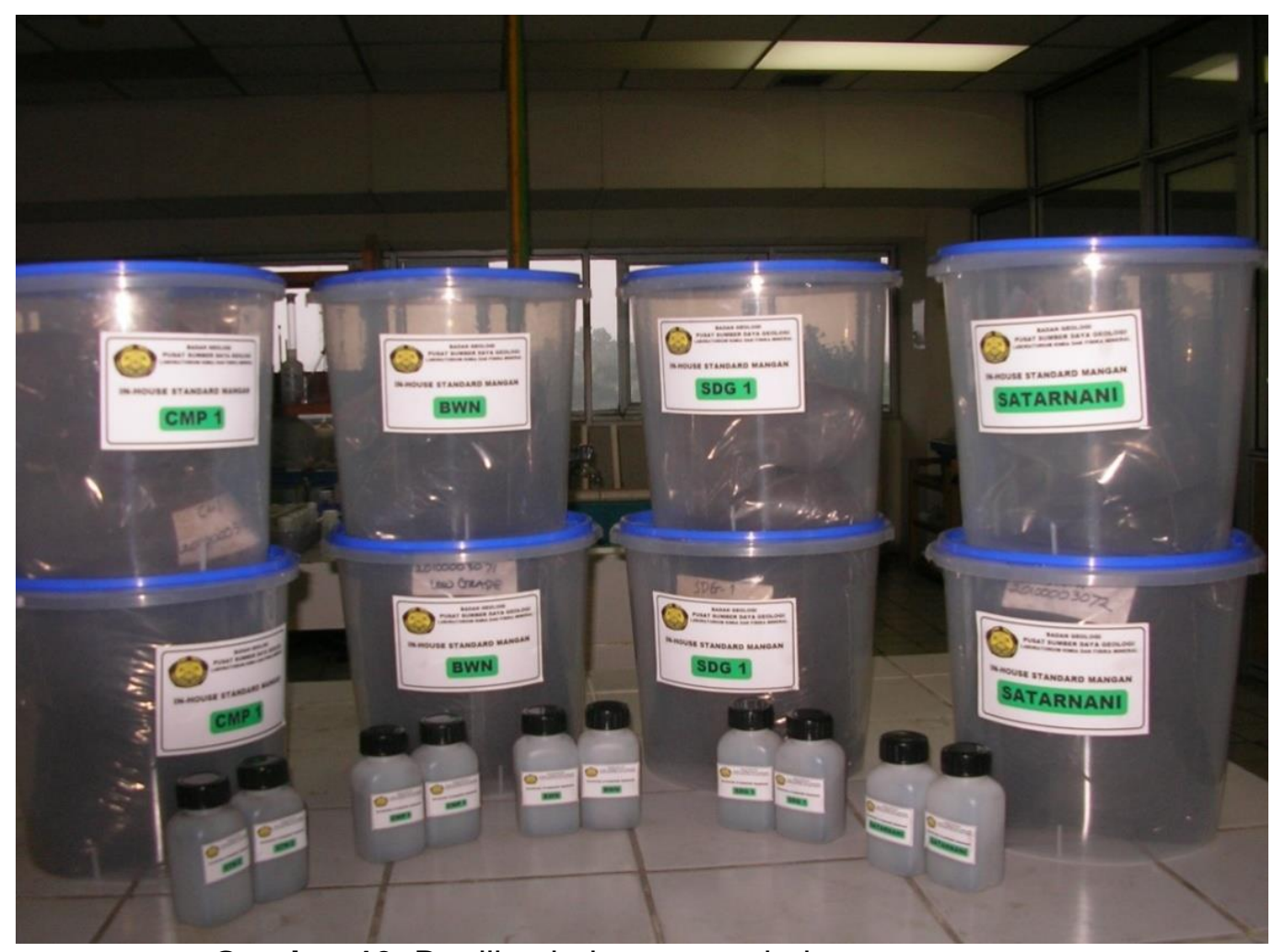

Gambar 19. Duplikat bahan acuan baku conto mangan

\section{HASIL DAN ANALISIS}

Berdasarkan hasil pengolahan data dari hasil analisis conto mangan pada lima conto yang dilakukan di internal Laboratorium Pusat Sumber Daya Mineral, Batubara dan Panas Bumi, kadar Mn total pada kode conto STN-2 52,92\%; BWN 35,28\%; SATARNANI 44,23\%; SDG-1 48,93\%; dan CMP-1 51,37\%. Hasil analisis secara terperinci berikut kandungan mineralnya seperti tertera Tabel 3.

Analisis conto mangan di luar Laboratorium Pusat Sumber Daya Mineral, Batubara dan Panas Bumi (Laboratorium A) dilakukan di tujuh laboratorium, yaitu di Pusat Penelitian dan Pengembangan Teknologi Mineral dan Batubara (Laboratorium B), Balai Besar Keramik (Laboratorium C), Balai Besar Barang dan Bahan Teknik (Laboratorium D), Badan Tenaga Atom Nasional (Laboratorium E), Geo Services (Laboratorium F), Intertek Utama Services (Laboratorium G), dan Pusat Survei Geologi (Laboratorium $\mathrm{H}$ ), dan dengan parameter $\mathrm{SiO}_{2}, \mathrm{Al}_{2} \mathrm{O}_{3}, \mathrm{Fe}_{2} \mathrm{O}_{3}$,
$\mathrm{MnO}_{2}, \mathrm{Mn}$ total, $\mathrm{MnO}, \mathrm{P}_{2} \mathrm{O}_{5}, \mathrm{~S}$ total, $\mathrm{H}_{2} \mathrm{O}^{-}$, dan HD.

Hasil analisis empat conto yaitu kode conto STN-2, BWN, SATARNANI dan SDG-1 dipilih sesuai dengan kriteria untuk katagori kadar Mn sedang dan tinggi, sedangkan untuk kode conto CMP-1 tidak dilakukan analisis kimia di tujuh laboratorium lainnya, karena termasuk kriteria Mn kadar tinggi yang sudah terwakili oleh kode conto STN-2. Hasil analisis conto mangan dari delapan laboratorium seperti terlihat pada Tabel 4 untuk kode conto STN-2, Tabel 5 untuk kode conto BWN. Tabel 6 untuk kode conto Satarnani, dan Tabel 7 untuk kode conto SDG-1. Laboratorium A, B, C, D dan $\mathrm{E}$, menggunakan metoda $A A S$, Spectrophotometer, Volumetri dan Gravimetri. Sedangkan Laboratorium F, G dan $\mathrm{H}$ metoda XRF. Semua hasil laboratorium dihitung pada conto kering pada suhu $105^{\circ} \mathrm{C}$. Tanda $\left({ }^{*}\right)$ pada ke empat tabel di atas menandakan data outlayer, sedangkan tanda $\left({ }^{* *}\right)$ menandakan data tak terpakai. 
Tabel 3. Hasil analisis major elements dan kandungan mineralnya

\begin{tabular}{|c|c|c|c|c|c|c|c|c|c|c|}
\hline \multirow[b]{2}{*}{ Unsur } & \multicolumn{2}{|c|}{ STN-2 } & \multicolumn{2}{|c|}{ BWN } & \multicolumn{2}{|c|}{ SATARNANI } & \multicolumn{2}{|c|}{ SDG-1 } & \multicolumn{2}{|c|}{ CMP-1 } \\
\hline & $\begin{array}{c}\text { Kadar } \\
(\%)\end{array}$ & $\begin{array}{l}\text { Presisi } \\
\text { internal }\end{array}$ & $\begin{array}{c}\text { Kadar } \\
(\%)\end{array}$ & $\begin{array}{l}\text { Presisi } \\
\text { internal }\end{array}$ & $\begin{array}{l}\text { Kadar } \\
(\%)\end{array}$ & $\begin{array}{l}\text { Presisi } \\
\text { internal }\end{array}$ & $\begin{array}{l}\text { Kadar } \\
(\%)\end{array}$ & $\begin{array}{l}\text { Presisi } \\
\text { internal }\end{array}$ & $\begin{array}{c}\text { Kadar } \\
(\%)\end{array}$ & $\begin{array}{c}\text { Presisi } \\
\text { internal }\end{array}$ \\
\hline $\mathrm{SiO}_{2}$ & 3,55 & 0,23 & 0,31 & 0,08 & 1,79 & 0,20 & 0,43 & 0,03 & 8,76 & 0,38 \\
\hline $\mathrm{Al}_{2} \mathrm{O}_{3}$ & 0,07 & 0,02 & 0,23 & 0,02 & 0,39 & 0,02 & 0,20 & 0,01 & 1,06 & 0,01 \\
\hline $\mathrm{Fe}_{2} \mathrm{O}_{3}$ & 0,64 & 0,02 & 0,13 & 0,01 & 0,60 & 0,01 & 0,23 & 0,01 & 0,36 & 0,01 \\
\hline Mn total & 52,92 & 0,11 & 35,28 & 0,20 & 44,23 & 0,07 & 48,93 & 0,16 & 51,37 & 0,22 \\
\hline $\mathrm{MnO}_{2}$ & 78,07 & 0,12 & 48,43 & 0,26 & 61,79 & 0,17 & 70,60 & 0,08 & 67,29 & 0,19 \\
\hline MnO & 4,64 & 0,14 & 6,04 & 0,43 & 6,70 & 0,09 & 5,73 & 0,16 & 11,43 & 0,34 \\
\hline $\mathrm{P}_{2} \mathrm{O}_{5}$ & 0,00 & 0,00 & 0,03 & 0,01 & 0,14 & 0,01 & 0,04 & 0,01 & 0,03 & 0,01 \\
\hline S.tot & 0,00 & 0,00 & 0,00 & 0,00 & 0,00 & 0,00 & 0,02 & 0,00 & 0,00 & 0,00 \\
\hline $\mathrm{H}_{2} \mathrm{O}^{-}$ & 1,48 & 0,02 & 1,30 & 0,06 & 1,03 & 0,02 & 2,67 & 0,05 & 1,35 & 0,04 \\
\hline HD & 14,08 & 0,02 & 25,66 & 0,07 & 20,77 & 0,04 & 18,86 & 0,18 & 10,25 & 0,09 \\
\hline Total & 101,04 & & 80,83 & & 92,19 & & 96,11 & & 99,19 & \\
\hline \multirow{3}{*}{$\begin{array}{c}\text { Kandungan } \\
\text { mineral }\end{array}$} & \multirow{2}{*}{\multicolumn{2}{|c|}{$\begin{array}{l}\text { Pirolusit }\left(\mathrm{MnO}_{2}\right) \\
\text { Muskovit (Clay) }\end{array}$}} & \multicolumn{2}{|c|}{ Kalsit $\left(\mathrm{CaCO}_{3}\right)$} & \multicolumn{2}{|c|}{ Kalsit $\left(\mathrm{CaCO}_{3}\right)$} & \multicolumn{2}{|c|}{ Kalsit $\left(\mathrm{CaCO}_{3}\right)$} & \multicolumn{2}{|r|}{-} \\
\hline & & & \multirow{2}{*}{\multicolumn{2}{|c|}{$\begin{array}{l}\text { Pirolusit ( } \mathrm{MnO}_{2} \text { ) } \\
\text { Muskovit (Clay) }\end{array}$}} & \multirow{2}{*}{\multicolumn{2}{|c|}{$\begin{array}{l}\text { Pirolusit }\left(\mathrm{MnO}_{2}\right) \\
\text { Muskovit (Clay) }\end{array}$}} & \multirow{2}{*}{\multicolumn{2}{|c|}{$\begin{array}{l}\text { Pirolusit }\left(\mathrm{MnO}_{2}\right) \\
\text { Muskovit (Clay) }\end{array}$}} & \multirow{2}{*}{\multicolumn{2}{|c|}{-}} \\
\hline & & & & & & & & & & \\
\hline
\end{tabular}

Tabel 4. Hasil analisis kode conto STN-2 dari delapan laboratorium

\begin{tabular}{|c|c|c|c|c|c|c|c|c|c|}
\hline Lab. & $\mathrm{SiO}_{2}$ & $\mathrm{Al}_{2} \mathrm{O}_{3}$ & $\mathrm{Fe}_{2} \mathrm{O}_{3}$ & $\begin{array}{c}\text { Mn } \\
\text { total }\end{array}$ & $\mathrm{MnO}_{2}$ & MnO & $\mathrm{P}_{2} \mathrm{O}_{5}$ & $\begin{array}{c}S \\
\text { total }\end{array}$ & HD \\
\hline & (\%) & (\%) & (\%) & (\%) & (\%) & (\%) & (\%) & (\%) & (\%) \\
\hline$A$ & $3,60^{\star *}$ & 0,06 & 0,64 & 53,71 & $79,24^{\star \star}$ & $4,70^{\star *}$ & $0,00^{* *}$ & 0,00 & 12,79 \\
\hline$B$ & $0,00^{* *}$ & $0,16^{*}$ & 0,57 & 53,20 & $83,40^{\star *}$ & $0,57^{* *}$ & 0,45 & 0,00 & 12,35 \\
\hline C & $0,57^{\star *}$ & $2,05^{\star *}$ & $0,41^{*}$ & $61,97^{*}$ & $84,04^{\star \star}$ & $1,02^{* *}$ & 0,44 & $0,07^{\star *}$ & 11,65 \\
\hline $\mathrm{D}$ & $1,03^{* *}$ & $0,66^{* *}$ & $1,30^{*}$ & $51,98^{*}$ & - & - & - & - & 13,23 \\
\hline$E$ & $0,34^{* *}$ & 0,04 & 0,68 & 55,84 & - & - & - & - & - \\
\hline$F$ & $5,32^{* *}$ & 0,14 & 0,65 & 55,14 & - & - & 0,41 & 0,00 & $13,52^{\star}$ \\
\hline $\mathrm{G}$ & $5,38^{* *}$ & 0,09 & $1,04^{*}$ & 55,31 & - & - & 0,37 & $0,02^{*}$ & 12,90 \\
\hline $\mathrm{H}$ & $4,10^{\star *}$ & $0,00^{*}$ & 0,62 & $59,65^{*}$ & - & - & $0,34^{*}$ & 0,00 & $13,55^{\star}$ \\
\hline Rata-rata & & 0,08 & 0,74 & 55,85 & & & 0,40 & 0,00 & 12,85 \\
\hline SD & & 0,06 & 0,29 & 3,37 & & & 0,05 & 0,01 & 0,68 \\
\hline Presisi & & 0,06 & 0,23 & 3,17 & & & 0,05 & 0,01 & 0,61 \\
\hline
\end{tabular}

Tabel 5. Hasil analisis kode conto BWN dari delapan laboratorium

\begin{tabular}{cccccccccc}
\hline \multirow{2}{*}{ Lab. } & $\mathrm{SiO}_{2}$ & $\mathrm{Al}_{2} \mathrm{O}_{3}$ & $\mathrm{Fe}_{2} \mathrm{O}_{3}$ & $\begin{array}{c}\mathrm{Mn} \\
\text { total }\end{array}$ & $\mathrm{MnO}_{2}$ & $\mathrm{MnO}$ & $\mathrm{P}_{2} \mathrm{O}_{5}$ & $\begin{array}{c}\mathrm{S} \\
\text { total }\end{array}$ & $\mathrm{HD}$ \\
\cline { 2 - 10 } & $(\%)$ & $(\%)$ & $(\%)$ & $(\%)$ & $(\%)$ & $(\%)$ & $(\%)$ & $(\%)$ & $(\%)$ \\
\hline $\mathrm{A}$ & $0,31^{* *}$ & 0,23 & 0,14 & 35,74 & $49,19^{* *}$ & $6,01^{* *}$ & $0,03^{*}$ & 0,00 & 24,68 \\
\hline $\mathrm{B}$ & 0,95 & $0,06^{*}$ & 0,14 & 34,20 & $53,50^{* *}$ & $0,51^{* *}$ & $0,51^{* *}$ & 0,00 & 24,40 \\
\hline $\mathrm{C}$ & $1,26^{*}$ & $2,06^{* *}$ & 0,13 & $55,28^{* *}$ & $75,61^{* *}$ & $2,79^{* *}$ & 0,12 & $0,07^{* *}$ & $18,02^{* *}$ \\
\hline $\mathrm{D}$ & 0,99 & $0,67^{* *}$ & $0,61^{* *}$ & $32,84^{*}$ & - & - & - & - & 24,68 \\
\hline $\mathrm{E}$ & $0,32^{* *}$ & 0,20 & 0,13 & 33,94 & - & - & - & - & - \\
\hline $\mathrm{F}$ & 0,74 & 0,25 & $0,03^{*}$ & 35,98 & - & - & 0,26 & 0,00 & 24,56 \\
\hline $\mathrm{G}$ & 0,80 & 0,16 & $0,27^{* *}$ & 34,45 & - & - & 0,22 & 0,00 & $23,70^{*}$ \\
\hline $\mathrm{H}$ & 0,78 & 0,25 & 0,09 & $37,92^{*}$ & - & - & 0,20 & 0,00 & 23,97 \\
\hline Rata2 & 0,92 & 0,19 & 0,11 & 35,01 & & & 0,17 & 0,00 & 24,33 \\
\hline SD & 0,19 & 0,07 & 0,04 & 1,67 & \multicolumn{7}{c}{0,09} & 0,00 & 0,45 \\
\hline Presisi & 0,19 & 0,07 & 0,04 & 1,49 & 0,00 & 0,45 \\
\hline
\end{tabular}


Tabel 6. Hasil analisis kode conto Satarnani dari delapan laboratorium

\begin{tabular}{cccccccccc}
\hline Lab. & $\mathrm{SiO}_{2}$ & $\mathrm{Al}_{2} \mathrm{O}_{3}$ & $\mathrm{Fe}_{2} \mathrm{O}_{3}$ & $\begin{array}{c}\mathrm{Mn} \\
\text { total }\end{array}$ & $\mathrm{MnO}_{2}$ & $\mathrm{MnO}$ & $\mathrm{P}_{2} \mathrm{O}_{5}$ & $\begin{array}{c}\mathrm{S} \\
\text { total }\end{array}$ & $\mathrm{HD}$ \\
\hline & $(\%)$ & $(\%)$ & $(\%)$ & $(\%)$ & $(\%)$ & $(\%)$ & $(\%)$ & $(\%)$ & $(\%)$ \\
\hline $\mathrm{A}$ & 1,93 & 0,40 & 0,61 & 44,69 & $62,43^{* *}$ & $6,77^{* *}$ & $0,14^{* *}$ & 0,00 & 19,95 \\
\hline $\mathrm{B}$ & $0,67^{* *}$ & $0,08^{*}$ & 0,57 & $41,60^{*}$ & $65,50^{* *}$ & $0,27^{* *}$ & 0,52 & 0,00 & 19,55 \\
\hline $\mathrm{C}$ & $0,59^{* *}$ & $1,54^{* *}$ & $0,29^{*}$ & $57,92^{* *}$ & $64,54^{* *}$ & $17,66^{* *}$ & 0,46 & $0,08^{* *}$ & $15,10^{* *}$ \\
\hline $\mathrm{D}$ & $2,47^{*}$ & $0,84^{* *}$ & $2,09^{* *}$ & $42,32^{*}$ & - & - & - & - & $20,11^{*}$ \\
\hline $\mathrm{E}$ & $0,15^{* *}$ & 0,25 & 0,43 & 44,74 & - & - & - & - & - \\
\hline $\mathrm{F}$ & 2,12 & 0,42 & 0,50 & $46,18^{*}$ & - & - & 0,52 & 0,00 & 20,03 \\
\hline $\mathrm{G}$ & 2,30 & 0,35 & $0,83^{*}$ & 43,45 & - & - & 0,47 & 0,00 & $19,50^{*}$ \\
\hline $\mathrm{H}$ & $1,73^{*}$ & 0,45 & 0,61 & $46,67^{*}$ & - & - & 0,44 & 0,00 & 19,89 \\
\hline Rata2 & 2,11 & 0,33 & 0,55 & 44,24 & & & 0,48 & 0,00 & 19,78 \\
\hline SD & 0,29 & 0,14 & 0,17 & 1,85 & & & 0,04 & 0,00 & 0,24 \\
\hline Presisi & 0,34 & 0,14 & 0,15 & 1,65 & & & 0,04 & 0,00 & 0,24 \\
\hline Kandungan mineral : kalsit $\left(\mathrm{CaCO}_{3}\right) ;$ pirolusit $\left(\mathrm{MnO}_{2}\right) ;$ muskovit (clay) &
\end{tabular}

Tabel 7. Hasil analisis kode conto SDG-1 dari delapan laboratorium

\begin{tabular}{|c|c|c|c|c|c|c|c|c|c|c|}
\hline Lab. & $\mathrm{SiO}_{2}$ & $\mathrm{Al}_{2} \mathrm{O}_{3}$ & $\mathrm{Fe}_{2} \mathrm{O}_{3}$ & $\begin{array}{l}\text { Mn } \\
\text { total }\end{array}$ & $\mathrm{MnO}_{2}$ & $\mathrm{MnO}$ & $\mathrm{P}_{2} \mathrm{O}_{5}$ & $S$ total & $\mathrm{HD}$ & \\
\hline & $(\%)$ & $(\%)$ & $(\%)$ & $(\%)$ & $(\%)$ & (\%) & $(\%)$ & $(\%)$ & $(\%)$ & \\
\hline A & 0,45 & 0,20 & 0,24 & 50,27 & $72,54^{* *}$ & $5,73^{\text {** }}$ & $0,04^{* *}$ & 0,02 & 16,63 & * \\
\hline$B$ & 0,50 & $0,05{ }^{*}$ & 0,21 & 46,10 & $72,80^{* *}$ & $0,13^{\text {** }}$ & $0,33^{*}$ & 0,00 & 17,17 & \\
\hline $\mathrm{C}$ & 0,71 & $10,38^{* \star}$ & 0,20 & 45,71 & $55,05^{* *}$ & $19,35^{* *}$ & $0,71^{* *}$ & 0,04 & 13,96 & ** \\
\hline$D$ & 0,71 & $0,51^{*}$ & $1,14^{* *}$ & 45,34 & - & - & - & - & 18,11 & * \\
\hline$E$ & $0,22^{*}$ & 0,15 & 0,09 & 50,09 & - & - & - & - & - & \\
\hline $\mathrm{F}$ & 0,53 & 0,24 & 0,08 & 50,30 & - & - & 0,25 & 0,00 & 17,20 & \\
\hline$G$ & 0,80 & 0,19 & $0,47^{\text {** }}$ & 50,30 & - & - & 0,22 & 0,03 & 16,80 & \\
\hline $\mathrm{H}$ & 0,94 & $0,44^{*}$ & 0,20 & 53,07 & - & - & 0,22 & 0,00 & 18,37 & * \\
\hline $\begin{array}{l}\text { Rata- } \\
\text { rata }\end{array}$ & 0,61 & 0,26 & 0,18 & 48,90 & & & 0,26 & 0,02 & 17,38 & \\
\hline SD & 0,23 & 0,16 & 0,07 & 2,81 & & & 0,05 & 0,02 & 0,71 & \\
\hline Presisi & 0,18 & 0,15 & 0,07 & 2,29 & & & 0,06 & 0,02 & 0,70 & \\
\hline
\end{tabular}

Kandungan mineral : kalsit $\left(\mathrm{CaCO}_{3}\right)$; pirolusit $\left(\mathrm{MnO}_{2}\right)$; muskovit (clay)

Data rekapitulasi hasil analisis dari delapan laboratorium yang melaksanakan proses analisis terhadap empat conto mangan, setelah dilakukan pengujian melalui metode statistik, maka conto mangan dengan kode conto STN-2 mempunyai kadar $\mathrm{Mn}$ total $55,85 \%$, kode conto BMW 35,01\%, kode conto Satarnani $44,24 \%$ dan kode conto SDG- $148,90 \%$. Secara lengkap hasil analisis kimia terhadap empat conto yang dianalisis oleh delapan laboratorium dapat dilihat pada
Tabel 8. Hasil analisis laboratorium dihitung dalam conto kering $105^{\circ} \mathrm{C}$ dan $\mathrm{MnO}_{2}$ dihitung dari $\mathrm{Mn}$ total.

Berdasarkan hasil rekapitulasi analisis delapan laboratorium conto mangan dengan kriteria kadar $\mathrm{Mn}$ total sedang (kode conto BWN 35,01\%) dan kadar Mn tinggi (kode conto SATARNANI 44,24\%; SDG-1 48,90\%; dan STN-2 55,85\%), hasil analisis secara terperinci tertera pada Tabel 8. 
metoda yang tepat untuk analisis jenis conto mangan ini dan belum menggunakan standar conto (CRM) yang sesuai, sehingga hasilnya kurang akurat (Sumadi, 2007).

Data $\mathrm{MnO}_{2}$ yang sangat diharapkan karena merupakan mineral utama atau unsur utama dalam conto mangan, datanya tidak dapat diolah dan dianalisis, karena data dari tujuh laboratorium lain umumnya $\mathrm{MnO}_{2}$ hanya dihitung dari kadar unsur Mn. Hal ini kemungkinan beberapa laboratorium tersebut tidak mempunyai prosedur analisis kimia untuk itu. Dari sejumlah laboratorium pengujian yang telah terakreditasi, hanya beberapa laboratorium saja yang dapat menganalisis mineral khususnya untuk conto mangan.

\section{KESIMPULAN DAN SARAN}

\section{Kesimpulan}

Laboratorium Pusat Sumber Daya Mineral, Batubara dan Panas Bumi memiliki bahan acuan baku analisis untuk conto mangan dengan katagori kadar sedang (30\% s.d. $44 \%$ ) dan tinggi (> 44\%). Conto bahan acuan baku tersebut dikemas dalam botol plastik, dengan berat masing-masing 100 gram, tersedianya bahan acuan baku conto mangan ini diharapkan dapat menjamin mutu dan akurasi hasil analisis pengujian conto mangan.

Data hasil analisis bahan acuan baku yang dibuat Laboratorium Pusat Sumber Daya Mineral, Batubara dan Panas Bumi, memberikan hasil dan presisi yang baik, dengan metode yang valid.

\section{Saran}

Kegiatan eksplorasi mangan dapat ditingkatkan di lingkungan Pusat Sumber Daya Mineral, Batubara dan Panas Bumi, mengingat laboratorium telah mempunyai bahan acuan baku analisis untuk conto mangan.

Pembuatan bahan acuan baku komoditi lainnya perlu dilakukan agar dapat meningkatkan kinerja laboratorium dan menghindarkan ketergantungan pada negara lain.

\section{UCAPAN TERIMA KASIH}

Penulis mengucapkan terima kasih kepada rekan-rekan di Laboratorium Pusat Sumber Daya Mineral, Batubara dan Panas Bumi khususnya Laboratorium Mineral Bukan Logam dan Panas bumi yang telah membantu, sehingga pembuatan bahan acuan baku analisis untuk conto mangan ini dapat diselesaikan dengan lancar. Ucapan terima kasih kami sampaikan juga kepada Dewan Redaksi yang telah membantu dalam penulisan makalah ini.

\section{DAFTAR PUSTAKA}

Anonim, 2004, Pedoman Perhitungan Statistik untuk Uji Profisiensi, Komite Akreditasi Nasional, Jakarta.

--------, 2008, Guidance for Statistical Evaluation of Interlaboratory Proficiency Testing Program, DACG3-03, Dubai Accreditation Center, Dubai.

--------, 2010, Manganese, page 12, Ideas $1^{\text {st }}$ Research, Sector, Metal and Mining Industry, Ferrous Metals, Mumbai-India.

---------, 2016, Mineral Strategis di Kabupaten/Kota, Pusat Sumber Daya Mineral, Batubara dan Panas Bumi, Badan Geologi, KESDM, Bandung.

Davis, A. E. and Hartati, R. D., 1991, The Preparation of Quality Control Sample for The Analysis of Sample from Southern Sumatra Geological and Mineral Exploration Project, Laporan Kerja, Direktorat Sumber Daya Mineral, Bandung.

Elishian, C., 2014, Metode-Metode Statistik dalam Evaluasi Data Hasil Uji Profisiensi, Pusat Penelitian LIPI, Banten.

Kartika, S. H., 2006, Buku Materi Pokok 6 Analisis Data Statistik STA 211/III/06. 
Maxwell, J., 1981, Rock and Mineral Analysis, Chemical Analysis, Second edition vol. 27, John Wiley and Sons, Canada.

Riyanto, 2014, Validasi dan Verifikasi Metode Uji sesuai dengan ISO/IEC 17025 Laboratorium Pengujian dan Kalibrasi, Penerbit Deepublish Yogyakarta, ISBN 978.

Scott, W. W., 1939, Standard Methods of Chemical Analysis, New York.

Shapiro, L., 1978, Rapid Analysis of Silicate, Carbonate and Phosphate Rock Revised Edition Geological Survey Buletin 1401.
Sukmana, 2006, Inventarisasi Mangan di Kabupaten Manggarai dan Kabupaten Manggarai Barat, Provinsi Nusa Tenggara Timur, Pusat Sumber Daya Geologi, Bandung.

Sumadi, K., 2007, Bahan Acuan untuk Uji Kompetensi, Homogenitas Bahan Acuan, Uji Stabilitas Conto Acuan, Kompetensi Kemampuan Pengujian Antar Analis, Puslitbang Teknologi Mineral dan Batubara, Bandung.

$\begin{array}{ll}\text { Diterima } & : 14 \text { Januari } 2018 \\ \text { Direvisi } & : 26 \text { Februari } 2018 \\ \text { Disetujui } & : 27 \text { April } 2018\end{array}$

